\title{
Prevalence of IgM and IgG antibodies to West Nile virus among blood donors in an affected area of north-eastern Italy, summer 2009
}

P Pezzotti (pezzotti@asplazio.it) ${ }^{1}$, C Piovesan ${ }^{2}$, L Barzon ${ }^{3,4}$, R Cusinato ${ }^{4}$, M Cattai $^{4}$, M Pacenti $^{4}$, A Piazza $^{4}$, E Franchin ${ }^{3,4}$,



1. Lazio Sanità - Agenzia di Sanità Pubblica (Public Health Agency), Rome, Italy

2. Direction of Prevention, Veneto region, Venice, Italy

3. Department of Histology, Microbiology, and Medical Biotechnologies, University of Padua, Padua, Italy

4. Regional Reference Centre for Infectious Diseases, Microbiology and Virology Unit, Hospital of Padua, Padua, Italy

5. Dipartimento Interaziendale di Medicina Trasfusionale (DIMT; Interinstitutional Department of Transfusion Medicine), Local Health Unit AUSL 18-19, Rovigo, Italy

6. Coordinamento Regionale per le Attività Trasfusionali (CRAT; Regional office for the coordination of blood transfusions), Pieve di Soligo, Italy

7. Department of Infectious Diseases, Istituto Superiore di Sanità, Rome, Italy

Citation style for this article:

Pezzotti P, Piovesan C, Barzon L, Cusinato R, Cattai M, Pacenti M, Piazza A, Franchin E, Pagni S, Bressan S, Martello T, Potenza R, Scipioni C, Ammendola R, Breda A, Palù G, Russo F, Rezza G. Prevalence of IgM and IgG antibodies to West Nile virus among blood donors in an affected area of north-eastern Italy, summer 2009 . Euro Surveill. 2011;16(10):pii=19814. Available online: http://www.eurosurveillance.org/ViewArticle.aspx?Articleld=19814

Article published on 10 March 2011

Following reports of West Nile neuroinvasive disease in the north-eastern area of Italy in 2009, all blood donations dating from the period between 1 August and 31 October 2009 in the Rovigo province of the Veneto region were routinely checked to exclude those with a positive nucleic acid test for West Nile virus (WNV). Only one of 5,726 blood donations was positive (17.5 per 100,000 donations; 95\% confidence interval (CI): $0.4-97.3)$. In addition, a selection of 2,507 blood donations collected during the period from 20 July to 15 November 2009 were screened by ELISA for IgG and IgM antibodies against WNV. A positive result was received for 94 of them. The positive sera were further evaluated using immunofluorescence and plaque reduction neutralisation test (PRNT), in which only 17 sera were confirmed positive. This corresponds to a prevalence of 6.8 per 1,000 sera ( $95 \% \mathrm{Cl}: 4.0-10.9)$. In a case-control study that matched each of the 17 PRNTpositive sera with four negative sera with the same date of donation and same donation centre, we did not find a significant association with age and sex of the donor; donors who worked mainly outdoors were significantly more at risk to have a positive PRNT for WNV.

\section{Introduction}

West Nile virus (WNV) was originally identified in 1937 in northern Uganda [1]. Birds, especially those in the Corvidae family are the natural reservoir of the virus, which is mainly transmitted to humans through the bite of infected Culex mosquitoes [2,3]. Transmission through receipt of blood products and transplantation has also been documented $[4,5]$. Rare cases of vertical transmission (i.e. transplacentally or through breast milk) and laboratory-acquired infection have also been reported [6].
During the last 20 years, several WNV outbreaks have occurred throughout the world. In addition to the United States [7], where the virus was first identified in $1999[2,3,6]$, large WNV outbreaks have also been reported in Europe and in the Mediterranean basin $[8,9]$. The largest European outbreak occurred in 1996 in Bucharest, Romania [10]. In the Mediterranean area, the first outbreak of human encephalitis was identified in the Camargue, France, in 1962 [11], followed by other epidemics in the 1990 s involving a relatively high number of human cases in Algeria [8], Tunisia [12] and Israel $[13,14]$. In the past few years, cases of WNV encephalitis have also been reported in the Volgograd region in Russia [15], in Hungary [16] and Romania [17], and very recently in Greece [18].

In Italy, the first outbreak of WNV infection was reported in 1998 in horses in Tuscany [19]. The virus reemerged in north-eastern Italy in summer 2008, when equine cases of WNV neuroinvasive infection were notified in the regions Veneto and Emilia Romagna [20]. An extraordinary WNV surveillance programme was subsequently activated, which led to the notification of nine human cases of West Nile neuroinvasive disease (WNND) in the summer of $2008[21,22]$ and a further 16 cases in late summer 2009; all cases occurred in the regions Emilia Romagna, Veneto and Lombardia, in wet areas surrounding the Po river [23-25].

Since WNV infection is generally asymptomatic with encephalitis occurring in less than $1 \%$ of cases, we conducted a seroepidemiology investigation in the Rovigo province in northern Italy, where a high incidence of WNND was observed, in order to estimate the extent of the epidemic and to better plan intervention strategies. 
Methods

\section{Setting}

The study area was the province of Rovigo, Veneto region, north-east Italy. This province, which has around 250,000 inhabitants, borders with the Po river and the Emilia-Romagna region. All territory is a level land characterised by extraordinary biodiversity, mainly because of the presence of freshwater and brackish water wetlands, including flooded deciduous woodlands, open lagoons of shallow water and river mouths. The high humidity level makes this area particularly attractive for mosquitoes, in particular during summer. It is located at the crossroads of bird migration routes connecting Europe, the Mediterranean basin and Africa, hosting a high number and wide range of migrating birds throughout the year. Thus, the high concentration of mosquitoes and migrating birds creates opportunities for vector-borne viruses such as WNV [26].

\section{Study design}

The study involved the three blood donation centres of Rovigo province which collected about 18,500 blood donations in 2009. During the period from 1 August to 31 October 2009, all blood donations were routinely evaluated by nucleic acid amplification test (NAAT) for WNV to identify potentially viraemic donations. In order to study the prevalence of WNV in the area, we tested, during the period from 20 July to 15 November 2009, serum samples from 25 blood donations per day for IgG and IgM antibodies to WNV. Any IgM- or IgGpositive sample was further evaluated by immunofluorescence and by plaque-reduction neutralisation test (PRNT) for confirmation. The number of serum samples collected at each centre was proportional to the volume of donations performed in the year 2008. Thus, each day, five donations were sampled from Adria (Centre 1), five from Trecenta (Centre 2), and 15 from

\section{TABLE 1}

Serological results of serum samples positive in the West Nile virus ELISA screening, Rovigo province, Italy, 20 July-15 November 2009 ( $n=94)$

\begin{tabular}{|c|c|c|c|c|}
\hline IgG ELISA & IgM ELISA & IgG IFA & IgM IFA & $\begin{array}{l}\text { Number of } \\
\text { samples }\end{array}$ \\
\hline \multicolumn{4}{|c|}{ Confirmed positive by PRNT } & 17 \\
\hline+ & + & + & + & 7 \\
\hline+ & - & + & - & 9 \\
\hline+ & + & + & - & 1 \\
\hline \multicolumn{4}{|c|}{ Not confirmed positive by PRNT } & 77 \\
\hline+ & - & + & - & 46 \\
\hline+ & - & + & + & 3 \\
\hline+ & - & - & - & 19 \\
\hline+ & + & + & - & 1 \\
\hline- & + & + & + & 2 \\
\hline- & + & - & + & 1 \\
\hline- & + & - & - & 5 \\
\hline
\end{tabular}

ELISA: enzyme-linked immunosorbent assay; IFA:

immunofluorescence assay; PRNT: plaque reduction neutralisation test.
Rovigo (Centre 3), choosing serum samples from the first consecutive daily donors who gave their consent to the study. All samples were handled anonymously by technicians and researchers involved in this study.

To evaluate potential risk factors associated with WNV infection, a case-control study matched by day and donation centre was performed. More specifically, for all donors that had IgG and/or IgM to WNV confirmed by PRNT, specific information about age, sex, address and type of job was retrospectively collected. For each positive donor, we collected the same information from four negative cases who were randomly chosen among the donors seen on the same day in the same centre. Although details on the type of job were collected, we decided after preliminary analysis to create a dummy variable classifying the job as done predominantly in the open air or not, e.g. a builder was classified as an open-air worker while a bank clerk's work was classified as indoors.

\section{Laboratory testing}

WNV NAAT screening was performed using Cobas Taq Screen West Nile Virus test on a Cobas s201 system (Roche Molecular Systems) on pools of aliquots from six individual plasma specimens. Specimens included in WNV RNA-positive pools were re-tested individually with the same WNV NAAT kit.

WNV IgM and IgG testing was done using the WNV IgM capture DxSelect ELISA and IgG DxSelect ELISA kits (Focus Diagnostics), respectively, as reported [18]. All serum samples which tested positive in the ELISA were further analysed by anti-West Nile virus IIFT IgG and IgM immunofluorescence assays (IFA) (Euroimmun AG), and, to rule out cross-reactivity with other flaviviruses and confirm the result, also with the PRNT, according to the previously described protocol [18].

\section{Statistical analysis}

Prevalence of antibodies to WNV was calculated as the ratio between sera confirmed positive by PRNT and all tested sera. The $95 \%$ confidence intervals $(\mathrm{Cl})$ of the prevalence were calculated using the binomial distribution. Prevalence estimates were also stratified by blood donation centre and by month of donation. Chisquare test was used to evaluate if the prevalence by blood donation centre and by month of donation was statistically significant.

Sensitivity, specificity, positive predictive (PPV) and negative predictive value (NPV) of IgG and IgM with respect to PRNT were also calculated, assuming that all sera not evaluated by PRNT were negative. This assumption favours highest estimates for specificity and NPV.

Odds ratios (OR) were calculated to evaluate the association between age, sex and open-air/indoors job of the donor with confirmed positivity by PRNT compared 
TABLE 2

Sensitivity, specificity, negative and positive predictive value of serological tests for West Nile virus, compared with PRNT, Rovigo province, Italy, 20 July to 15 November $2009(n=2,507)$

\begin{tabular}{|c|c|c|c|c|c|c|}
\hline & PRNT-positive & PRNT-negative & PPV & NPV & Sensitivity & Specificity \\
\hline \multicolumn{7}{|l|}{ WNV ELISA } \\
\hline IgM-positive/lgG-positive & 8 & 1 & 88.9 & 99.6 & 47.1 & 100.0 \\
\hline other & 9 & 2,489 & & & & \\
\hline IgM-positive/IgG-negative & 0 & 8 & 0.0 & $99 \cdot 3$ & 0.0 & 99.7 \\
\hline other & 17 & 2,482 & & & & \\
\hline IgM-negative/IgG-positive & 9 & 68 & 11.7 & 99.7 & 52.9 & 97.3 \\
\hline other & 8 & 2,422 & & & & \\
\hline ELISA-positive & 17 & 77 & 18.1 & 100.0 & 100.0 & 96.9 \\
\hline ELISA-negative & 0 & 2,413 & & & & \\
\hline \multicolumn{7}{|l|}{ WNV IFA ${ }^{a}$} \\
\hline IgM-positive/lgG-positive & 7 & 5 & 58.3 & 99.6 & 41.2 & 99.8 \\
\hline Other & 10 & 2,485 & & & & \\
\hline IgM-positive/IgG-negative & 0 & 1 & 0.0 & 99.3 & 0.0 & 100.0 \\
\hline other & 17 & 2,489 & & & & \\
\hline IgM-negative/IgG-positive & 10 & 47 & 17.5 & 99.7 & 58.8 & 98.1 \\
\hline other & 7 & 2,443 & & & & \\
\hline IFA-positive & 17 & 53 & 24.3 & 100.0 & 100.0 & 97.9 \\
\hline IFA-negative & 0 & 2,437 & & & & \\
\hline
\end{tabular}

ELISA: enzyme-linked immunosorbent assay; IFA: immunofluorescence assay; NPV: negative predictive value; PPV: positive predictive value; PRNT: plaque reduction neutralisation test.

a WNV IFA is evaluated as a second line test for WNV ELISA-positive samples.

Note: It was assumed that all sera tested negative by ELISA would also have been negative in IFA and PRNT even when these tests were not performed.

TABLE 3

Adjusted odds ratios of being PRNT-positive for West Nile virus, associated with blood donor characteristics, conditional logistic model, Rovigo province, Italy, 20 July-15 November 2009 ( $\mathrm{n}=17$ )

\begin{tabular}{|c|c|c|c|c|c|c|c|c|}
\hline & & \multicolumn{2}{|c|}{ PRNT-positive } & \multicolumn{2}{|c|}{ PRNT-negative ${ }^{a}$} & \multirow[t]{2}{*}{ AOR } & \multirow[t]{2}{*}{$95 \% \mathrm{Cl}$} & \multirow[t]{2}{*}{$\mathrm{p}$} \\
\hline & & $\mathrm{N}$ & $\%$ & $\mathrm{~N}$ & $\%$ & & & \\
\hline \multirow{3}{*}{ Age (years) } & $<40$ & 5 & 23,8 & 16 & 76,2 & 1.00 & & \\
\hline & $47-53$ & 4 & 19,0 & 17 & 81,0 & 0.48 & $0.09-2.45$ & 0.37 \\
\hline & $>53$ & 4 & 19,0 & 17 & & 0.69 & $0.15-3.23$ & 0.64 \\
\hline \multirow{2}{*}{ Sex } & Male & 16 & 20,5 & 62 & 79,5 & 1.00 & & \\
\hline & Female & 1 & 14,3 & 6 & 85,7 & 0.88 & $0.09-8.75$ & 0.92 \\
\hline Indoor/outdoor & Indoors & 5 & 16,2 & 57 & 83,8 & 1.00 & & \\
\hline \multirow[t]{2}{*}{ working activity } & Outdoors & 11 & 38,5 & 8 & 61,5 & 5.07 & $1.01-25.37$ & 0.05 \\
\hline & Unknown & 1 & 25.0 & 3 & 75.0 & 2.74 & $0.20-37.38$ & 0.45 \\
\hline
\end{tabular}

AOR: adjusted odds ratios; $\mathrm{Cl}$ : confidence interval; PRNT: plaque reduction neutralisation test.

a PRNT-negative blood donors were matched to positive ones by day and centre of donation. 
to matched sera not tested/not confirmed by PRNT. The OR was calculated taking into account matching by day and blood donation centre. A conditional logistic model was used to simultaneously adjust the OR for the effect of each evaluated factor with respect to the others.

\section{Results}

During the period from 1 August to 31 October 2009, 5,726 blood donations were collected in Rovigo province and tested by WNV NAAT. One blood donation, not included in the seroprevalence study, was WNV RNApositive (17.5 per 100,000 donations; $95 \% \mathrm{Cl}$ : $0.4-$ 97.3). Details on this positive case have been reported previously [25].

Among the 2,507 serum samples evaluated for IgG and IgM, 94 (3.7\%) were positive in the WNV ELISA IgG and/ or IgM screening and further tested by IFA and PRNT (Table 1). Of the 94 ELISA-positive samples, 70 (75\%) were also WNV IFA-positive and 17 (18\%) were confirmed by PRNT. The PRNT-confirmed cases included eight ( $47 \%$ ) cases with both WNV IgM and IgG and nine ( $53 \%$ ) with only WNV IgG detected by ELISA and/or IFA.

The estimated overall prevalence of WNV antibodies confirmed by PRNT was 6.8 per 1,000 tested sera $(95 \%$ $\mathrm{Cl}$ : 4.0-10.9). Stratifying by month of donation no particular fluctuations were observed, with prevalences that varied from 6.2 per 1,000 in September to 7.6 in October $(p=0.99$, Chi-square test, data not shown). The prevalence differed significantly by blood donation centre, with the highest prevalence in Trecenta (17.9 per 1,000 donations) and the lowest in Adria and Rovigo (4.0 per 1,000 donations) (p<0.01).

Table 2 shows the sensitivity, specificity, positive predictive value (PPV) and negative predictive value (NPV) of WNV ELISA alone and WNV ELISA followed by WNV IFA as a second-line test compared with PRNT results as the gold standard, and assuming that all ELISA-negative samples that were not also evaluated by PRNT, would have been negative in the PRNT. The sensitivity of WNV IgM detection for predicting WNV infection was low, whether by ELISA alone or by a combination of ELISA and IFA; however, the possibility of false negative results of PRNT at early phases of infection was not excluded in this study. The sensitivity of WNV IgG detection, either alone or in combination with WNV IgM detection by ELISA was about 50\%. The addition of WNV IFA as a second-line test for ELISA-positive samples did not improve test sensitivity and PPV.

Table 3 shows the association of the blood donors' characteristics with being WNV positive in PRNT in a matched case-control analysis. While age and sex were not found to be significantly associated with being WNV-positive in PRNT, working outdoors was associated with a statistically significant higher risk ( $>5$ times) of WNV infection than working indoors $(p=0.05)$.
Finally, a map of the province was produced, plotting the geographical coordinates of the PRNT-positive donors and the cases of WNND notified in 2009 and resident in the Rovigo province. Most subjects with a PRNT-confirmed WNV infection lived close to rivers in western areas of the Rovigo province, without any apparent clustering or association with the place of residence of subjects diagnosed with WNND (data not shown).

\section{Discussion}

In accordance with national guidelines [27] that recommend screening of blood donations in affected areas where at least one human case with WNND has been detected, all blood donations performed in Rovigo province during summer 2009 were individually tested by NAAT. Only one of 5,726 blood donations resulted positive by NAAT, which corresponds to an estimated risk of WNV transmission of about 17.5 per 100,000 blood donations. With the limitation of the small samples size in our study, this risk appears to be lower than that reported in the United States during the peak of the WNV epidemic in 2002 [28] and in Canada in the period from 2006 to 2007 [29].

In order to estimate the extent of WNV infection among humans, we also conducted a serosurvey in a selection of blood donations in the study area; the estimated overall prevalence of anti-WNV antibodies was 6.8 per 1,000 sera ( $95 \% \mathrm{Cl}: 4.0-10.9)$. This prevalence estimate was lower than that found in a previous survey $(15.6$ per 1,000), that was conducted in the same province but was restricted to a population considered at risk of environmental exposure represented by farm employees who worked in areas where WNVseropositive horses had been identified [22].

A retrospective screening of solid organ donors in several Italian regions found a higher prevalence of anti-WNV antibodies than the present study on blood donors [30]. This discrepancy could be accounted for by differences in target populations and sampling strategies as well as laboratory methods used for testing and for confirmation of positive results. We considered as positive only those samples which were confirmed by neutralisation assays. In fact, less than $20 \%$ of WNV ELISA-positive samples were confirmed by PRNT. After combining ELISA and IFA, the specificity did not increase significantly for those samples which were positive in both tests. Since the PPV of a test tends to decrease in low prevalence areas, our results suggest that neutralisation assays should be used to confirm positive results, especially in areas with a low risk of infection.

The prevalence in our study varied widely among geographical areas, ranging from about 18 per 1,000 blood donations in Trecenta to 4.0 per 1,000 in Adria and Rovigo. Moreover, the geographical distribution of infected individuals suggested that most cases were resident in areas near rivers and other water sources. 
This is consistent with other studies on WNV and other mosquito-borne infections, such as La Crosse encephalitis [3,31]. However, we could not evaluate the association between WNV seroprevalence and proximity to water sources in our samples because of the lack of available geo-reference data on WNV-negative blood donations. For the same reason, any factor explaining the geographical variation could not be evaluated due to limited environmental data.

With regard to risk factors for infection, no statistically significant difference was found for age or sex, while a statistically significant association was found with working outdoors compared with other jobs. These findings, which suggest a higher risk of exposure to mosquito bites, contradict studies conducted in Romania, where having spent more than six hours outdoors during the day was not found associated with West Nile virus infection [32].

In conclusion, this study estimated the seroprevalence of WNV among blood donors of an affected area of Italy as 6.8 per 1,000 sera and indicates that WNV seroprevalence can vary widely even between different geographical areas within the same province. Although WNV NAT-positive samples were rare in our population, blood screening is needed in order to reduce the risk of WNV transmission to vulnerable recipients.

\section{References}

1. Smithburn KC, Hughes TP, Burke AW, Paul JH. A neurotropic virus isolated from the blood of a native of Uganda. Am J Trop Med. 1940; s1-20(4):471-92.

2. Campbell GL, Martin AA, Lanciotti RS, Gubler DJ. West Nile virus. Lancet Infect Dis. 2002;2(9):519-29.

3. Granwehr BP, Lillibridge KM, Higgs S, Mason PW, Aronson JF, Campbell GA, et al. West Nile virus: where are we now? Lancet Infect Dis. 2004;4(9):547-56.

4. Iwamoto M, Jernigan DB, Guasch A, Trepka MJ, Blackmore CG, Hellinger WC, et al. Transmission of West Nile virus from an organ donor to four transplant recipients. N Engl J Med. 2003;348(22):2196-203.

5. Pealer LN, Marfin AA, Petersen LR, Lanciotti RS, Page PL, Stramer SL, et al. Transmission of West Nile virus through blood transfusion in the United States in 2002. N Engl J Med. 2003;349(13):1236-45.

6. Conly JM, Johnston BL. Why the West in West Nile virus infection? Can J Infect Dis Med Microbiol. 2007;18(5):285-8.

7. Nash D, Mostashari F, Fine A, Miller J, O'Leary D, Murray K, et al. The outbreak of West Nile virus infection in the New York City area in 1999. N Engl J Med. 2001;344(24):1807-14.

8. Murgue B, Murri S, Triki H, Deubel V, Zeller HG. West Nile in the Mediterranean basin: 1950-2000. Ann N Y Acad Sci. 2001;951:117-26.

9. Zeller HG, Schuffenecker I. West Nile virus: an overview of its spread in Europe and the Mediterranean basin in contrast to the spread in the Americas. Eur J Clin Microbiol Infect Dis. 2004;23(3):147-56.

10. Tsai TF, Popovici F, Cernescu C, Campbell GL, Nedelcu NI. West Nile encephalitis epidemic in southeastern Romania. Lancet. 1998;352(9130):767-71.

11. Panthier R. Epidemiologie du virus West Nile: étude d'un foyer en Camargue. I: Introduction. [Epidemiology of West Nile virus: study of an outbreak in the Camargue I: Introduction]. Annales de l'Institute Pasteur 1968;114: 519-20. French.

12. Feki I, Marrakchi C, Ben Hmida M, Belahsen F, Ben Jemaa M, Maaloul I, et al. Epidemic West Nile virus encephalitis in Tunisia. Neuroepidemiology. 2005;24(1-2):1-7.

13. Siegel-Itzkovich J. Twelve die of West Nile virus in Israel. BMJ.. 2000;321(7263):724.
14. Weinberger M, Pitlik SD, Gandacu D, Lang R, Nassar F, Ben David D, et al. West Nile fever outbreak, Israel, 2000: epidemiologic aspects. Emerg Infect Dis. 2001;7(4):686-91.

15. Platonov AE, Shipulin GA, Shipulina OY, Tyutyunnik EN, Frolochkina TI, Lanciotti RS, et al. Outbreak of West Nile virus infection, Volgograd Region, Russia, 1999. Emerg Infect Dis. 2001;7(1):128-32.

16. Krisztalovics K, Ferenczi E, Molnar Z, Csohan A, Ban E, Zoldi V, et al. West Nile virus infections in Hungary, AugustSeptember 2008. Euro Surveill. 2008;13(45):pii=19030. Available from: http://www.eurosurveillance.org/ViewArticle. aspx?Articleld $=19030$

17. Sirbu A, Ceianu CS, Panculescu-Gatej RI, Vázquez A, Tenorio A, Rebreanu R, et al. Outbreak of West Nile virus infection in humans, Romania, July to October 2010. Euro Surveill. 2011;16(2):pii=19762. Available from: http://www. eurosurveillance.org/ViewArticle.aspx?Articleld=19762

18. Papa A, Danis K, Baka A, Bakas A, Dougas G, Lytras T, et al. Ongoing outbreak of West Nile virus infections in humans in Greece, July-August 2010. Euro Surveill. 2010;15(34):pii=19644. Available from: http://www. eurosurveillance.org/ViewArticle.aspx?Articleld=19644

19. Autorino GL, Battisti A, Deubel V, Ferrari G, Forletta R, Giovannini A, et al. West Nile virus epidemic in horses, Tuscany region, Italy. Emerg Infect Dis. 2002;8(12):1372-8.

20. Macini P, Squintani G, Finarelli AC, Angelini P, Martini E, Tamba $M$, et al. Detection of West Nile virus infection in horses, Italy, September 2008. Euro Surveill. 2008;13(39):pii=18990. Available from: http://www.eurosurveillance.org/ViewArticle. aspx?Articleld $=18990$

21. Gobbi F, Napoletano G, Piovesan C, Russo F, Angheben $A$, Rossanese A, et al. Where is West Nile fever? Lessons learnt from recent human cases in northern Italy. Euro Surveill. 2009;14(10):pii=19143. Available from: http://www. eurosurveillance.org/ViewArticle.aspx?Articleld=19143

22. Barzon L, Squarzon L, Cattai M, Franchin E, Pagni S, Cusinato $\mathrm{R}$, et al. West Nile virus infection in Veneto region, Italy, 2008-2009. Euro Surveill. 2009;14(31):pii=19289. Available from: http://www.eurosurveillance.org/ViewArticle. aspx?Articleld=19289

23. Angelini P, Tamba M, Finarelli AC, Bellini R, Albieri A, Bonilauri $P$, et al. West Nile virus circulation in EmiliaRomagna, Italy: the integrated surveillance system 2009. Euro Surveill. 2010;15(16): pii=19547. Available from: http://www. eurosurveillance.org/ViewArticle.aspx?Articleld=19547

24. Rizzo C, Vescio F, Declich S, Finarelli AC, Macini P, Mattivi A, et al. West Nile virus transmission with human cases in Italy, August-September 2009. Euro Surveill. 2009;14(40):pii=19353. Available from: http://www.eurosurveillance.org/ViewArticle. aspx?Articleld $=19353$

25. Barzon L, Franchin E, Squarzon L, Lavezzo E, Toppo S, Martello $\mathrm{T}$, et al. Genome sequence analysis of the first human West Nile virus isolated in Italy in 2009. Euro Surveill. 2009;14(44):pii= 19384. Available from: http://www.eurosurveillance.org/ ViewArticle.aspx?Articleld $=19384$

26. Rezza G. Chikungunya and West Nile virus outbreak: what is happening in north-eastern Italy? Eur J Public Health. 2009;19(3):236-7.

27. Grazzini G, Liumbruno GM, Pupella S, et al. West Nile virus in Italy: a further threat to blood safety, a further challenge to the blood system. Blood Transfus. 2008;6(4):235-7.

28. O’Brien SF, Scalia V, Zuber E, Hawes G, Alport EC, Goldman M, et al. West Nile virus in 2006 and 2007: the Canadian Blood Services' experience. Transfusion. 2010;50(5):1118-25.

29. Busch MP, Wright DJ, Custer B, Tobler LH, Stramer SL, Kleinman $\mathrm{SH}$, et al. West Nile virus infections projected from blood donor screening data, United States, 2003. Emerg Infect Dis. 2006;12(3):395-402.

30. Capobianchi MR, Sambri V, Castilletti C, Pierro AM, Rossini G, Gaibani P, et al. Retrospective screening of solid organ donors in Italy, 2009, reveals unpredicted circulation of West Nile virus. Euro Surveill. 2010;15(34): $\mathrm{pii}=19648$. Available from: http://www.eurosurveillance.org/ViewArticle. aspx?Articleld $=19648$

31. Haddow AD, Jones CJ, Odoi A. Assessing risk in focal arbovira infections: are we missing the big or little picture? PLoS One. 2009;4(9):e6954.

32. Han LL, Popovici F, Alexander JP Jr, Laurentia V, Tengelsen LA, Cernescu C, et al. Risk factors for West Nile virus infection and meningoencephalitis, Romania, 1996. J Infect Dis. 1999;179(1):230-233 